\title{
Gender Profile on Cultivation and Post-Harvest of Cassava Farming in Gunungkidul Regency Yogyakarta
}

\author{
Titiek Widyastuti \\ Department of Agrotechnology, Faculty of Agriculture \\ Universitas Muhammadiyah Yogyakarta \\ Yogyakarta, Indonesia \\ titiekw@umy.ac.id
}

\begin{abstract}
This research aimed to determine the gender profiles in cultivation and post-harvest of cassava farming. The location of the study was chosen based on cassava planting area in each district, namely the largest (Saptosari), medium (Tanjungsari), smallest (Purwosari), using descriptive analysis research method. The sampling was carried out by purposive sampling, on households that had cassava farming from three districts, where 20 households were selected from each district, so the total number of respondents was 60 households. The data collection techniques were observation, interview, and recording. The data analysis used graph assistance. In addition, gender analysis wasalso applied, covering 5 aspects: participation, access, control, benefits, and impacts. The result of this study showed that on cassava farming in Gunungkidul there iss good cooperation and role-sharing between women and men. The gender profile of cassava farming in Gunungkidul showed that in plant cultivation, male participation is greater than female participation, whereas in post-harvest activities female participation is relatively greater than male participation. Women's access and control are lower than those of men, except in marketing. Women and men feel the benefits of cassava farming. The real impact of the existence of cassava farming is an increase in women's consumptive behavior (purchasing clothes and food).
\end{abstract} Profile

Keywords-Cassava, Cultivation and Post-Harvest, Gender

\section{INTRODUCTION}

Cassava (Manihot utilissima) is included in Euphorbiaceae family [1]. In Indonesia, cassava plants spread in various regions, especially in marginal areas. In special region of Yogyakarta, the highest cassava production is in Gunungkidul Regency (99.91\%), followed by Kulon Progo Regency $(0.07 \%)$, and Bantul Regency $(0.02 \%)$. In Gunungkidul Regency, cassava production is the highest compared to the production of other food crops. The high production level of cassava is understandable because of the soil conditions, most of them are farmland or not technically irrigated rice fields, so that the cropping pattern must be adjusted to seasonal conditions, and cassava plant is the most suitable to cultivate in Gunungkidul [2]. Cassava cultivation in Gunungkidul spreads throughout the districts, the largest is in Saptosari Subdistrict and the smallest one is in Purwosari Subdistrict
(BPS Gunungkidul, 2015). Cassava is one of the primary foods for Gunungkidul society, in addition to rice. As a food ingredient, cassava is usually sold as raw material such as tubers, tapioca, gaplek, pellets, and various processed foods [3]. In addition, cassava is also used as raw material for mocaf and bioethanol [4]. The commodity of cassava becomes one of the strategic food ingredients that can be used as a substitute for rice as the staple food to support the success of the food diversification program in Gunungkidul area. For this reason, the Agricultural Extension and Food Security Agency of Gunungkidul encourages cassava farmers to innovate so the yields increase and have a high selling value [5]. The Government of Gunungkidul Regency will strengthen the cassava farmer institutions, so that all the processes, starting from planting to selling products can be well done [6]

Cassava is one of Indonesia's local carbohydrate sources which ranks the third after rice and corn and is the most potential raw material for processing into flour [7]). Cassava has many benefits: it can be used as food, feed, and industry. As food, almost all parts of cassava are edible, namely: tubers, young leaves, stems, yams. Cassava industrial waste in the form of peel and onggok can be used as a mixture of animal feed, the cassava leaves that are melted can be used as animal feed. Cassava can also be used as a raw material for various industries, for examples: the industry of alcohol, ethanol, gasohol, glue, textiles, and chemical industry, and raw materials for food industries such as gaplek and tapioca, as well as ready-made foods such as chips, enyek-enyek, emping, and biscuits [8].

Technically, cassava cultivation and post-harvest activities are carried out by both men and women as labor. Therefore, in order to meet the expected results of cassava cultivation and post-harvest activities, there should be equality in agricultural science and skills between men and women as farmers. Cassava farming needs to be handled professionally in order to provide crop yields and increase farmers' income levels as expected. To achieve these objectives, correct handling must be implemented since the preparation of land and seeds, cultivation, harvesting, post-harvesting, and marketing of products. The field data showed that the cultivation and postharvest of cassava involved both male and female farmers, but there was the so-called segmentation of the types of work. Generally, the division between male and female labors in 
cassava cultivation and post-harvest is based on experiences they get from their parents. Knowledge, skills, and experience of cassava farmers in cultivation and post-harvest are some factors that influence the success, so these need attention. In various fields, innovation in knowledge and technology is generally more accepted by men, yet femal farmers are less exposed to the agricultural development [9]. Empowering farmer family, by using clear area which gets social, economic, healthy and culture advantage [10]. The contribution of women in agriculture is significant, especially in the economy of the family. However, this significant contribution does not come with equal opportunity and access to agricultural resources and other public facilities [11]. The limited knowledge and experience of cassava farmers in cultivation and post-harvest have not been extensively explored, even though these are essential in formulating programs or making policies in order to improve the quality of human resources for cassava farming. To empower cassava farmers, it is more appropriate by finding the real problems in the field. It is essential to find out about the gender profile in the cultivation and post-harvest of cassava farming and to identify the existing problems in order to be used in formulating some strategic steps for empowerment. Gender profile can be identified using gender analysis. Gender analysis is a form of social analysis that regular activities to identify and understand various things from male and female perspectives in the whole processes and stages of activities. Gender analysis is conducted to see the segmentation of the role and position of women, and in terms of cassava cultivation and post-harvest, it includes participation, access, control, benefits, impacts. Participation is defined as the involvement of women and men in cassava cultivation and post-harvest activities. Access is defined as opportunities for women and men to get resources related to cassava cultivation and post-harvest. Control is defined as the mastery / authority of women and men to make decisions in activities related to cultivation and post-harvest of cassava. Benefits are defined as things that can be obtained by women and men from cassava farming. Impact is defined as matters in cassava farming activities that can affect women and men [12]. This research aimed to determine the gender profiles in cultivation and post-harvest of cassava.

\section{METHODS}

The location of the study was selected based on the cassava planting area in each district [2], namely the largest (Saptosari), medium (Tanjungsari), smallest planting area (Purwosari), using descriptive analysis research method. The sampling was carried out by purposive sampling, on families who had cassava farming from three districts; 20 households were selected from each district, so the total number of respondents was 60 households. The data collection techniques were observation, interview, and recording. The data analysis used graph assistance. In addition, gender analysis was also applied, covering five aspects: participation, access, control, impact, and benefits

\section{RESULTS AND DISCUSSION}

On cassava farming in Gunungkidul, there are good cooperation and division of roles between women and men. Women and men have different gender-based roles and responsibilities, different knowledge of, access to, control over natural resources, and different opportunities to participate in decisions regarding natural resources use [13]. For workx in crop cultivation at all stages, male participation is greater than female participation. On the other hand, in post-harvest activities female participation is relatively greater than male participation, except for activities that require the power of man, such as collecting crops and transporting products. Male participation is greater than that of women because man as husband is the backbone of family, so that the amount of time spent by men is more than that by women; women are only seen as assistants. Because of a lack of gender awareness, in agricultural development projects women are usually not included as participants, and in routine programs they are not considered a target group [14]. Post-harvest activities are handled more by women than men, so the level of female participation in post-harvest is greater than that of men, except for activities that need the power of man, such as collecting crops and transporting products. The participation of women and men on cassava farming in Gunungkidul can be seen in Figure 1.

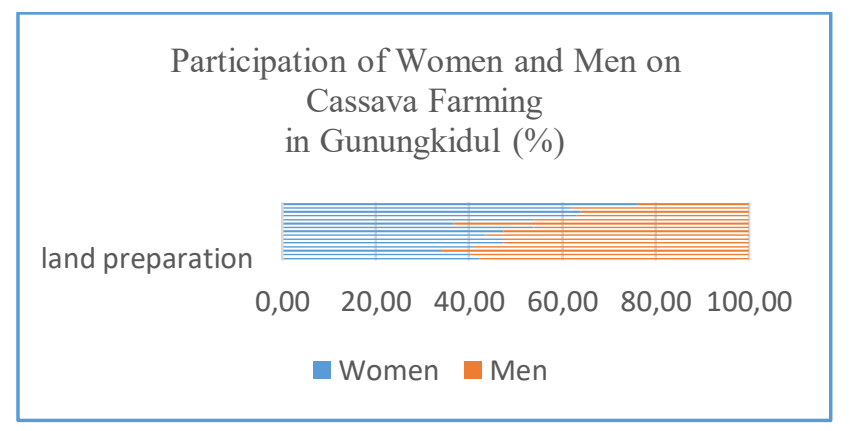

Figure 1. Participation of Women and Men in Cassava Farming in Gunungkidul (\%)

With regard to technological innovation, both women and men have access in line with their roles in farming. Women's access is in fact lower than men's access in terms of information, organization or association, land resources, procurement of production factors, utilization of agricultural machinery, product diversification, and labor. On the other hand, women's access is more than men's access in terms of tool procurement, marketing, utilization of agricultural machinery. Women's access to information is lower than that of men because the existing counseling is generally related to the problems of crop cultivation, in this case, the invitation and socialization are usually for men. While the training is mostly around post-harvest, allowing women to have more access in this case. The low access of women to the organization or society is because men are more dominant in public sector, while women are in domestic sector so that women's access to a number of activities is low. Women access to land resources is lower than men's access because men have roles as the main farmers, alowing them to have more access. On the other hand, 
women have more access to the procurement of cultivation tools and post-harvest due to the fact that women usually serve as family treasurers who know financial situation. In terms of land, it is indeed the authority of men, so that men's access to the procurement of production factors is more than that of women. The fact that men have more access to the use of agricultural machinery compared to women is related to the use of agricultural machinery which is more commonly used by men, so that men's access to the utilization of agricultural machinery is more than that of women. Meanwhile, the processing work of crops is usually done by women, so that women's access to processing equipment is more than that of men. Women also have more access to marketing compared to men because based on the existing habits, male farmers are more responsible for cultivation, whereas once the crops are harvested, the management is left to women. The lower access of women to labor compared to men's access is because men are considered more authoritative in determining labor, allowing them to have more access to labor more than women. Both the women and men's access on cassava farming in Gunungkidul can be seen in Figure 2.

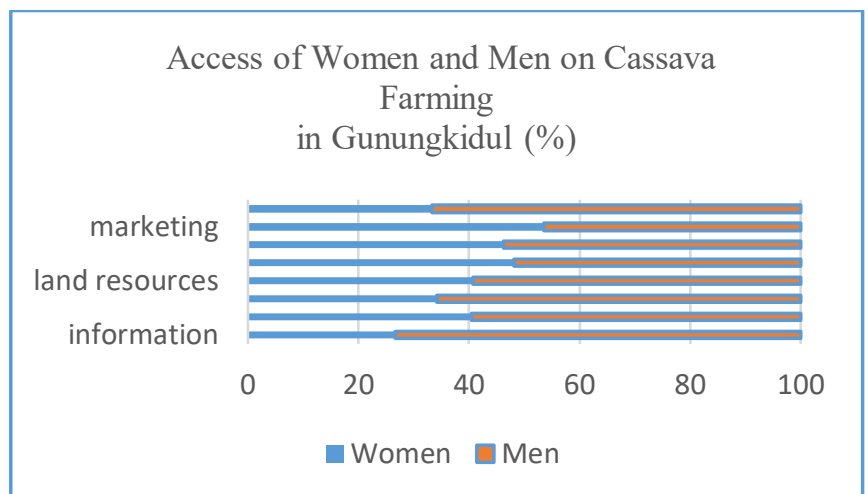

Figure 2. Access of Women and Men to Cassava Farming in Gunungkidul (\%)

In terms of technological innovation, both women and men have control in line with their roles in farming. Women's control is lower than men's control in terms of information, organization or association, land resources, procurement of factors of production, utilization of agricultural machinery, marketing (product diversification and pricing), labor, and information. On the other hand, women's control is higher than that of men in terms of utilization of crop processing tools, marketing (place, method, and marketing time). Women's control of information is lower than that of men because men are more active in the cultivation of plants, so men have more control over information from Field Extension Officers (PPL) than women. The lower control of women over counseling compared to that of men is in line with the role of men as the main actors in the cultivation of crops so that they more often receive invitation or opportunities to attend counseling. Regarding to the fact that women are more involved in postharvest activities, so control over training is higher. However, women have lower control over organization or society because men are more dominant in public sector, while women are in domestic sector, causing them to have lower control over these activities. Women's control over land resources is lower than that of men because men have roles as the main farmers, allowing them to have more control. In terms of the procurement of production factors, women's control is lower than men's control because men are more involved in cultivation activities. Women has more post-harvest involvement than men do, so control over the procurement of yield processing equipment is more than men. More control over the use of agricultural machinery belongs to men instead of women because agricultural machinery is more commonly used by men so that men's control over the utilization of agricultural machinery is more than that of women. On the other hand, the post harvest processes are mostly done by women so that the control of women over post harvest processing is more than that of men. That women have more control over marketing compared to men is because based on the existing habits, male farmers are more responsible for cultivation, while once the crops are harvested, the management is left to women. However, in terms of product diversification, men have more control because this is related to determining the activities or works where men usually have more control. That women have lower control over labor compared to men is because men are considered more authoritative in determining labor, allowing them to have more control than women. Both women and men's control on cassava farming in Gunungkidul can be seen in Figure 3.

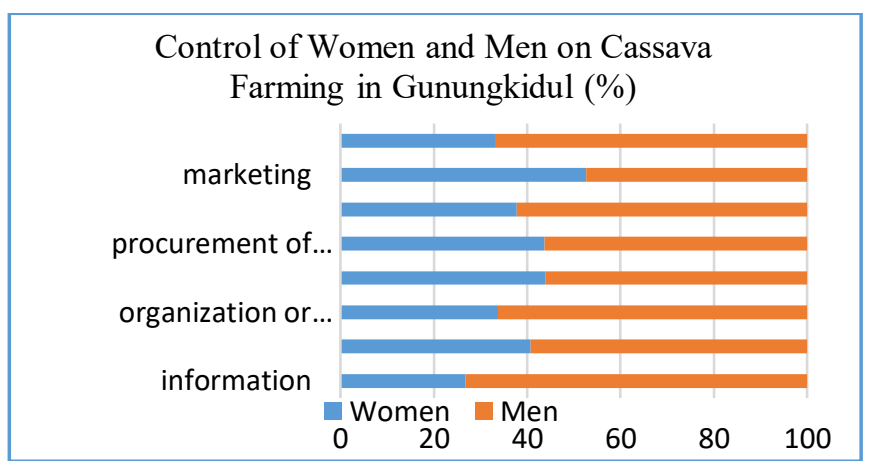

Figure 3. Control of Women and Men over Cassava Farming in Gunungkidul (\%)

Women perceive more practical benefits of cassava cultivation and post-harvest in terms of increased income, fulfillment of clothing and food needs, while men perceive more benefits of cassava farming in terms of asset ownership. The strategic benefits obtained from cassava farming are an increased insight, knowledge and skill perceived by both women and men, while women perceive more benefits of cassava farming in terms of an increase in social status. The benefits of cassava farming in increasing income and the fulfillment of food needsare equally perceived by women and men because income in this case refers to the income of family whose allocation is to fulfill family life needs. Similarly, the fulfillment of food needs also refers to the fulfillment for all family members, so both women and men perceive it the same way. However, men perceive more benefit from asset ownership compared to women because the tendency that exists in the community is to own assets in husband's name. On the other hand, the benefit of cassava farming towards the fulfillment of clothing, women perceive more of it because they are more likely to handle clothing necessary. The benefits of cassava farming in Gunungkidul can be seen in Figure 4. 


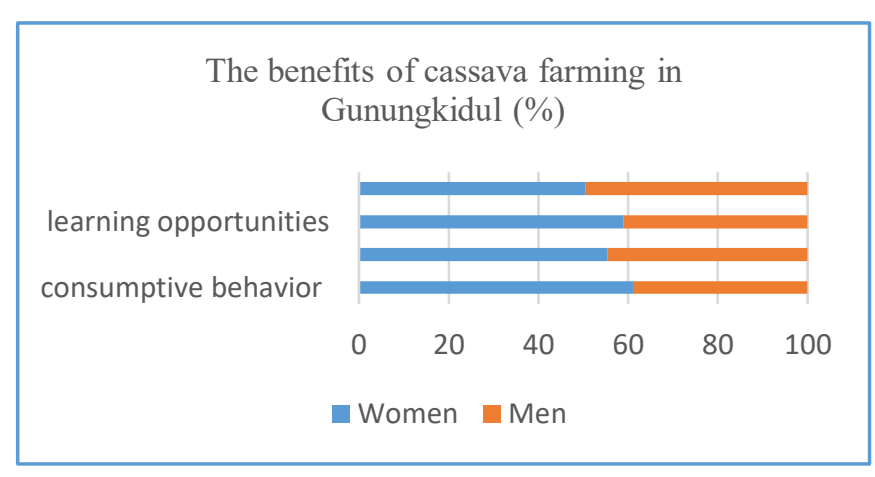

Figure 4. Benefits of cassava farming in Gunungkidul (\%)

The real impact of the existence of cassava farming is an increasing consumptive behavior of women. Besides, cassava farming also has an impact on participation in social activities and learning opportunities, which are perceived more by women. In addition, both women and men perceive equal impact on family harmony. The impact of cassava farming in Gunungkidul can be seen in Figure 4.

\section{CONCLUSION}

The result of this study shows that on cassava farming in Gunungkidul there are good cooperation and role-sharing between women and men. The gender profile of cassava farming in Gunungkidul shows that in plant cultivation, male participation is greater than female participation, whereas in post-harvest activities female participation is relatively greater than male participation. Women's access and control are lower than those of men, except in marketing. Women and men feel the benefits of cassava farming. The real impact of the existence of cassava farming is an increased consumptive behavior of women, especially in purchasing clothes and food.

\section{ACKNOWLEDGMENT}

This research was conducted using Internal Research Grant of Universitas Muhammadiyah Yogyakarta No: 1083/SP2PL/LP3M-UMY/IV/2017. Date: April 8, 2017.

The author would like to extend deep gratitude to Muzhajanah, Wiji, Isna, Gity, Ririn, Retno who are willing to collect the data for this research.

\section{REFERENCES}

[1] Steenis, J.V., Flora., Untuk Sekolah di Indonesia, Pradnya Paramita, Jakarta, 1975

[2] Bappeda Gunungkidul dan BPS Gunungkidul, Gunungkidul Dalam Angka 2015, Badan Pusat Statistik Kabupaten Gunungkidul. 2015

[3] Bargumono dan Suyadi, Singkong,, https://www.academia.edu/11932664/02.

[4] Supangkat, G. dan Sarjiyah, "Identifikasi singkong varietas lokal", Program studi Agroteknologi, Universitas Muhammadiyah Yogyakarta, Laporan Penelitian, 2016

[5] Sutarmi, "Petani Gunungkidul diminta melakukan inovasi, singkong",

[6] http://jogja.antaranews.com/berita/341356. 2016

[7] Anonim,. "Gunungkidul akan bentuk kelembagaan petani, Singkong", http://www.beritasatu.com/ekonomi/388694, 2016

[8] Badan Penelitian dan Pengembangan Pertanian, "Inovasi pengolahan singkong meningkatkan pendapatan”. Agroinovasi. 2008.
[9] Rukmana, R. dan Y. Yuniarsih, Aneka Olahan Singkong, Kanisius, Yogyakarta, 2007

[10] Sukesi, K., Teknik Analisis Jender, PPPW Lemlit UNIBRAW, Malang, 2002

[11] Machfudz, M., \& Khoiriyah, N., "Analisis ketahanan pangan melalui pemodelan usaha tani singkong”, Iqtishoduna, 2013

[12] Luthfi, A., "Akses dan kontrol perempuan petani penggarap pada lahan pertanian PTPN IX Kebun Merbuh”, Komunitas: International Journal of Indonesian Society and Culture, 2(2), 2010.

[13] Widyastuti, T., “Analisis jender”, Diklat Mahasiswa PTN/PTS se Kab. Jember, STAIN, Jember 5 Juli 2001

[14] Hendarto, K. A. (2002). "Proyek kehutanan sosial dan penganggaran berwawasan gender: Suatu ulasan teoritis", 2002

[15] Gerbangtani, "Teknologi pertanian menurut perspektif petani, perempuan".

https:/gerbangtani.wordpress.com/2012/12/29/teknologi-pertanianmenurut-perspektif-petani-perempuan/, 2012 